\title{
Analisis Program Pembelajaran Berbasis Higher Order Thinking Skills di MI At-Taqwa GUPPI Wojowalur Daerah Istimewa Yogyakarta Tahun Ajaran 2018/2019
}

\author{
Eka Yusnaldi ${ }^{1}$, Fia Alifah Putri ${ }^{2}$, Wahyu Iskandar ${ }^{3}$ \\ ${ }^{1}$ UIN Sumatera Utara, ${ }^{2}$ UIN Sunan Kalijaga Yogyakarta, \\ ${ }^{3}$ STIT Al- Ittihadiyah Labuhanbatu Utara \\ ekayusnaldi@uinsu.ac.id, fraalifahputri24@gmail.com, \\ wiskandar921@gmail.com
}

\begin{abstract}
The rules 2013 Curriculum is very interested in providing learning processes and items that have Higher Order Thinking Skills (HOTS) degrees for students. The HOTS function is very representative of providing logical, reflective, critical, creative and metacognitive abilities which are higher order thinking abilities. This study aims to determine the HOTS-based learning planning program in MI At-Taqwa GUPPI Wojowalur Yogyakarta Special Region 2018/2019 and HOTS-based learning implementation program in MI At-Taqwa GUPPI Wojowalur Yogyakarta Special Region 2018/2019. Data were analyzed by describing or describing data according to the rules of descriptive qualitative research by taking interview and documentation data. In determining the subject, the researcher used a non-probability sample. The results of this study that (1) HOTS learning program 2018/2019 school year teachers implement learning plans using syllabus and RPP based on HOTS (2) HOTS learning implementation program $2018 / 2019$ school year teachers have used variations in the determination of HOTS-based methods such as discussion, question and answer and students' ability to argue.
\end{abstract}

Keywords: Learning, HOTS, MI At-Taqwa GUPPI Wojowalur

Abstrak: Kebijakan Kurikulum 2013 sangat berkepentingan dalam memberikan proses pembelajaran dan butir soal yang memiliki derajat HOTS kepada peserta didik. Fungsi HOTS sangat representatif memberikan kemampuan logis, reflektif, kritis, kreatif dan metakognitif yang merupakan kemampuan berpikir tingkat tinggi. Penelitian ini bertujuan untuk mengetahui program perencanaan pembelajaran berbasis HOTS di MI At-Taqwa

AR-RIAYAH : Jurnal Pendidikan Dasar vol. 5, no. 1, 2021

IAIN Curup - Bengkulu 1 p ISSN 2580-362X; e ISSN 2580-3611

http://journal.iaincurup.ac.id/index.php/JPD

DOI: $10.29240 /$ jpd. v5i1.2523| p. $97-120$ 
GUPPI Wojowalur Daerah Istimewa Yogyakarta tahun ajaran 2018/2019 dan program pelaksanaan pembelajaran berbasis HOTS di MI At-Taqwa GUPPI Wojowalur Daerah Istimewa Yogyakarta tahun ajaran 2018/2019. Data dianalisis dengan cara dideskripsikan atau menggambarkan data sesuai kaidah penelitian kualitatif deskriptif dengan pengambilan data wawancara dan dokumentasi. Dalam menentukan subjek, peneliti menggunakan sampel non probability sampel. Adapun hasil penelitian ini bahwa (1) Program pembelajaran HOTS tahun ajaran 2018/2019 guru melaksanakan perencanaan pembelajaran dengan menggunakan silabus dan RPP yang berbasis HOTS (2) Program pelaksanaan pembelajaran HOTS tahun ajaran 2018/2019 guru sudah menggunakan variasi dalam penentuan metode yang berbasis HOTS seperti diskusi, tanya jawab dan kemampuan berargumentasi peserta didik.

Kata kunci: Pembelajaran, HOTS, MI At-Taqwa GUPPI Wojowalur

\section{PENDAHULUAN}

Peningkatan kualitas pendidikan dapat ditempuh dengan cara meningkatkan kualitas program pembelajaran yang meliputi perencanaan, proses dan penilaian pembelajaran1. Di mana ketiga hal ini jika semakin terus membaik akan menghasilkan kualitas pembelajaran yang baik. Program pembelajaran sendiri merupakan sub-unit dari kurikulum, di mana didalamnya serangkaian proses dari implementasi program pembelajaran di suatu lembaga pendidikan2. Setiap periodiknya, kurikulum mengalami pengembangan sesuai kebutuhan pendidikan. Troffler menganggap pembaharuan kurikulum sebuah niscaya yang harus dijalankan dengan mengikuti perkembangan jaman demi tercapainya kemajuan bangsa 3456.

1 Hartati Muchtar, "Penerapan Penilaian Autentik Dalam Upaya Peningkatan Mutu Pendidikan," Jurnal Pendidikan Penabur 14, no. 9 (2010): 68-76, https://www.academia.edu/download/51966178/jurnal-No14-Thn9-Juni2010.pdf\#page=76 .

2 Randi Pratama Murtikusuma, Arif Fatahillah, and Lioni Anka Monalisa, "Pengembangan Rancangan Pembelajaran Matakuliah Kombinatorika Berbasis Kerangka Kualifikasi Nasional Indonesia (KKNI) Dan Local Wisdom (Development of Combinatorics Learning Plan Based on NationalQualification Framework and Local Wisdom)," Jurnal edukasi 4, no. 3 (2014): 41-44, https://jurnal.unej.ac.id/index.php/JEUJ/article/view/6300 .

3 Troffer, Future Shock: A Book That Will Resphape Our Thinking (London: Prantice Hall, 1976). 
Harapan terhadap kemajuan bangsa inilah yang membuat kualitas pendidikan terus berevolusi menjadi lebih baik lagi salah satunya dengan melakukan perubahan. Perubahan kurikulum dari KTSP menjadi Kurikulum 2013 atau K-13 menuntut guru dapat mengembangkan dan meningkatkan kemampuan berpikir kritis dan kreativitas peserta didik. Di mana dalam proses pembelajaran guru dituntut melaksanakan pembelajaran yang aktif dengan pendekatan saintifik dan penilaian autentik7. Penilaian autentik merupakan penilaian yang dilakukan dengan melibatkan domain kognitif, afektif dan psikomotorik8.

Domain kognitif sendiri dapat mengukur kemampuan peserta didik dalam menjelaskan fakta, konsep, prosedur dan pengetahuan metakognitif. Dimana secara prosesnya domain kognitif ini secara sistematis tersusun dari mulai mengingat (remembering) sebagai $\mathrm{C} 1$, memahami (understanding) sebagai $\mathrm{C} 2$, menerapkan (applying) sebagai C3, menganalisis (analyzing) sebagai C4, menilai (evaluating) sebagai C5, dan mencipta (creating) sebagai C6. Dimana pada standar penilaian C4-C6 atau yang disebut Higher Order Thinking Skills (HOTS) atau keterampilan bepikir tingkat Tinggi merupakan sistem yang mulai digalakkan pemerintah dari tahun 2017/2018.

HOTS dalam kebijakan K-13, pemerintah menyarankan agar proses pembelajaran dan butir soal yang akan diberikan kepada peserta didik memiliki derajat HOTS. Kementerian Pendidikan dan Kebudayaan melalui Direktorat Jenderal Guru dan Tenaga Kependidikan (Ditjen GTK) meningkatkan kualitas pembelajaran yang bermuara pada peningkatan kualitas peserta didik dengan menyelenggarakan Program Peningkatan Kompetensi Pembelajaran (PKP). Progam PKP salah satu materinya adalah peningkatan kualitas peserta didik,

4 Loeziana Uce, "Realitas Aktual Praksis Kurikulum: Analisis Terhadap KBK, KTSP Dan Kurikulum 2013," Jurnal Ilmiah Didaktika 16, no. 2 (2016): 216-229, http://dx.doi.org/10.22373/jid.v16i2.596.

5 Anas Suprapto, "Posisi Dan Peran Guru Dalam Pola Kurikulum 2013," J-PAI: Jurnal Pendidikan Agama Islam 3, no. 1 (2016): 89-94, https://doi.org/10.18860/jpai.v3i1.3993 .

6 Wahyu Iskandar, Nur Rohman, and Muhammad Yusuf, "Kontribusi Pemikiran Imre Lakatos (1922-1974) Dalam Pendekatan Berbasis Saintifik Di Madrasah Ibtidaiyah," in Proceeding International Conference On Islamic Education (ICIED), 2019, 13-21, http://conferences.uinmalang.ac.id/index.php/icied/article/view/1060.

7 Fitri Indriani, "Kompetensi Pedagogik Mahasiswa Dalam Mengelola Pembelajaran Tematik Integratif Kurikulum 2013 Pada Pengajaran Micro Di PGSD UAD Yogyakarta," Jurnal Profesi Pendidikan Dasar 2, no. 2 (2015): 87-94, https://journal.upy.ac.id/index.php/es/article/view/362.

8 Ahmad Yani, Cara Mudah Menulis Soal HOTS Higher Order Tbinking Skilss Suatu Pendekatan "Jarak Nalar" Yang Dilengkapi Dengan Pembelajaran Berorientasi Keterampilan Berpikir Tingkat Tinggi (Bandung: PT Refika Aditama, 2019). 
yang dilakukan melalui peningkatan kualitas pembelajaran yang berorientasi pada keterampilan berpikir tingkat tinggi. Selain itu demi menunjangnya penerapan HOTS ini pemerintah menerbitkan beberapa buku diantaranya buku pegangan beroientasi HOTS9 pada tahun 2018 dan buku penilaian berorientasi HOTS10 pada tahun 2019.

HOTS dalam penerapannya memang sangat cocok diterapkan kepada peseta didik karena keterampilan ini perlu dilatih sejak usia sekolah dasar (SD) untuk membuat siswa terbiasa dengan cara berpikir yang akan menjadi modal belajar pada tingkat pendidikan berikutnya. Ini sejalan dengan tujuan pembelajaran matematika yang dapat membentuk kemampuan bernalar pada diri siswa yang tercermin melalui kemampuan bepikir logis, kritis, sistematis, dan memiliki sifat objektif, jujur, disiplin dan memecahkan suatu permasalahan dalam bidang matematika maupun dalam kehidupan sehai-hari. Dimana pembelajaran matematika ini perlu dipelajari dari mulai SD hingga perguruan tinggi11.

Keterampilan berpikir tingkat tinggi juga membuat siswa mampu menyampaikan ide-ide argumentatif, logis, dan percaya diri, baik tertulis, lisan, dan tindakan12. Menurut Kings, Goodson, dan Rohani, HOTS merupakan kemampuan berpikir yang tidak hanya membutuhkan kemampuan mengingat, tetapi juga kemampuan yang lebih tinggi. HOTS juga merupakan kemampuan siswa yang diaktifkan ketika siswa menghadapi masalah, ketidakpastian, pertanyaan, atau dilema yang tidak dikenal. Selain itu Pogrow menyatakan bahwa HOTS dihargai karena mereka diyakini dapat mempersiapkan siswa lebih baik untuk tantangan dalam kehidupan akademik yang maju dan bertanggung jawab setiap harinya. Oleh karena itu, HOTS dapat digunakan untuk memprediksi

9 Yoki Ariyana et al., Buku Pegangan Pembelajaan Berorientasi Pada Keterampilan Berpikir Tingkat Tinggi "Program Peningkatan Kompetensi Pembelajaran Berbasis Zonasi" (Jakarta: Direktorat Jenderal Guru dan Tenaga Kependidikan Kementrian Pendidikan dan Kebudayaan, 2018).

10 Wiwik Setiawati et al., "Program Pengembangan Keprofesian Berkelanjutan (PKB)

Melalui Peningkatan Kompetensi Pembelajaran (PKP) Berbasis Zonasi," in Buku Penilaian Beroientasi Higher Order Thinking Skills Jakarta: Direktorat Jendral Guru dan Tenaga Kependidikan Kementerian Pendidikan dan Kebudayaan, 2019).

11 Yuni Kastarina, Tegus S Karniman, and Anggraini, "Penerapan Model Pembelajaan Kooperatif Tipe Team Assisted Individualization Untuk Meningkatkan Hasil Belajar Siswa Pada Fungsi Komposisi Di Kelas XI IPA I SMAN 7 Palu," AKSIOMA Jurnal Pendidikan Matematika 5, no. 3 (2016): 269-281.

12 Usmaedi, "Menggagas Pembelajaran HOTS Pada Anak Usia Sekolah Dasar," JPSD 3, no. 1 (2017). 
keberhasilan seorang siswa. Siswa yang memiliki tingkat HOTS yang baik diharapkan berhasil dalam studi mereka nanti13.

Sejatinya, program pembelajaran kini diarahkan kepada mewujudkan anak yang memiliki kemampuan berpikir tingkat tinggi, serta diiringi dengan karakter individu dan sosial yang baik. Sehingga, melalui program pembelajaran yang diberikan mampu mencetak generasi unggul dan berkarakter bagi bangsa Indonesia.

Upaya analisa program pembelajaran sebagai "kunci dasar" implementasi pembelajaran berbasis HOTS telah dikaji dalam berbagai aspek. Di antaranya aspek asesmen berbasis HOTS1415, materi pembelajaran berbasis HOTS16, pengembangan soal ujian berbasis HOTS17, metode dan media pembelajaran berbasis HOTS18, desain pembelajaran berbasis HOTS19, peran pendidikan berbasis HOTS20 bagi kemajuan bangsa. Bahkan, upaya pelatihan pembelajaran berbasis HOTS21 juga tidak luput dikaji oleh para peneliti terdahulu.

13 Benidiktus Tanujaya, Jeinne Mumu, and Gaguk Margono, "The Relationship between Higher Order Thinking Skills and Academic Performance of Student in Mathematics Instruction," International Education Studies 10, no. 11 (2017): 78-85.

14 Rahayu Herawati, W S Rustono, and Ghullam Hamdu, "Pengembangan Asesmen Hots Pada Pembelajaran Berbasis Masalah Tema Bermain Dengan Benda-Benda Di Sekitar," PED ADID AKTIKA: Jurnal Ilmiah Pendidikan Guru Sekolab Dasar 1, no. 2 (2017): 151-159.

15 Erna Yayuk, Tyas Deviana, and Nawang Sulistyani, "Kemampuan Guru Dalam Implementasi Pembelajaran Dan Penilaian HOTS Pada Siswa Kelas 4 Sekolah Indonesia Bangkok Thailand," JINOP (Jurnal Inovasi Pembelajaran) 5, no. 2 (2019): 107-122.

16 Sriyono, Nurhidayati Anni Prastiwi, "Pengembangan Modul Fisika Berbasis Masalah Untuk Meningkatkan High Order Thinking Skills (Hots) Siswa Sma," RADIASI: Jurnal Berkala Pendidikan Fisika 9, no. 1 (2016): 1-6.

17 Anggi Lestari, Asep Saepulrohman, and Ghullam Hamdu, "Pengembangan Soal Tes

Berbasis HOTS Pada Model Pembelajaran Latihan Penelitian Di Sekolah Dasar” (2016): 74-83.

18 R Mursid, Abdul Hasan Saragih, and Naeklan Simbolon, "Pengaruh Media

Pembelajaran Berbasis TIK Dan Sikap Inovasi Terhadap Hasil Belajar Perencanaan

Pembelajaran Dengan HOTS," Jurnal Teknologi Informasi \& Komunikasi Dalam Pendidikan 4, no. 2 (2017): 179-187.

19 Eko Kuntarto, Alirmansyah Alirmansyah, and Agung Rimba Kurniawan, "Kemampuan Mahasiswa PGSD Dalam Merancang Dan Melaksanakan Pembelajaran Berbasis High Order Of Thinking Skills," Jurnal Kiprah 7, no. 2 (2019): 107-116.

20 Ramadhan Prasetya Wibawa and Dinna Ririn Agustina, "Peran Pendidikan Berbasis Higher Order Thinking Skills (Hots) Pada Tingkat Sekolah Menengah Pertama Di Era Society 5.0 Sebagai Penentu Kemajuan Bangsa Indonesia," EQUILIBRIUM Jurnal Ilmiah Ekonomi dan Pembelajarannya 7, no. 2 (2019): 137-141.

21 Meita Fitrianawati and Aan Hendroanto, "Pelatihan Pembelajaran Berbasis HOTS Dan Pendidikan Matematika Realistik Bagi Guru SD Di Kabupaten Sleman,” no. September (2019): $1-7$. 
Dari fenomena dan literature review di atas, diketahui bahwa masih terdapat "ruang kosong" kajian mendalam berupa upaya analisis program pembelajaran secara sistemik mulai dari perencanaan, dan pelaksanaan. Untuk itu, diperlukan suatu penelitian sebagai upaya menemukan sudah sampai sejauh mana kemampuan keterampilan guru dalam analisis program pembelajaran berstandar HOTS. Peneliti memilih MI At-Taqwa GUPPI Wojowalur ini dikarenakan jaraknya yang cukup jauh dari kota Yogyakarta dan masuk ke dalam kabupaten Kulon Progo. Peneliti ingin mengetahui apakah pogram pembelajaran HOTS yang sudah dicanangkan oleh pemerintah sudah merata diberikan atau diterapkan di MI yang jaraknya cukup jauh dari Kota Yogyakarta yang dijuluki sebagai kota pendidikan tersebut. Dengan menganalisis MI tersebut diharapkan jadi bahan referensi penelitian-penelitian yang akan membahas mengenai HOTS dan juga penelitian terhadap MI yang berada di kabupaten Kulon Progo serta diharapkan penelitian ini menjadi pemicu agar guru dan berbagai pihak yang terlibat senantiasa dapat melakukan perbaikan terhadap kualitas pendidikan di Indonesi. Dengan demikian, dilakukan riset dengan judul, "Analisis Program Pembelajaran Berbasis HOTS Tahun Ajaran 2018/2019.”

\section{METODE PENELITIAN}

Penelitian ini dilakukan di MI At-Taqwa GUPPI Wojowalur Daerah Istimewa Yogyakarta dengan menggunakan penelitian kualitatif yang bersifat deskriptif dengan cara mendeskripsikan atau menggambarkan data yang telah terkumpul sebagaimana adanya tanpa bermaksud membuat generalisasi22. Jenis penelitian ini sangat cocok untuk menganalisis dan mendeskripsikan program pembelajaran bebasis HOTS dengan pengambilan data wawancara dan dokumentasi. Penentuan subjek dilakukan dengan menggunakan teknik purposive sampling yang merupakan sampel dengan penentuan pertimbangan tertentu23. Penentuan pertimbangan tersebut diantaranya adalah narasumber yang bekaitan langsung dengan program pembelajaran serta naasumber yang akrab dengan pemberian soal-soal yang menjadi bahan evaluasi pembelajaran. Dengan begitu yang dijadikan sebagai narasumber adalah Guru kelas 6 sebagai narasumber terkait. Kemudian data di analisis menggunakan analisis data deskriptif untuk menelaah dengan membaca, mengkaji dan mencatat soal dengan tujuan sudah sampai sejauh mana program pembelajaran yang berlangsung baik dari segi

22 Karunia Eka Lestari and Mokhamad Ridwan Yudhanegara, Penelitian Pendidikan Matematika (Bandung: Refika Aditama, 2017).

23 Ibid. 
program pembelajaran yang meliputi perencanaan ataupun pelaksanaan pembelajaran.

\section{HASIL DAN PEMBAHASAN}

Higher Order Thinking Skills (HOTS) merupakan salah satu komponen dari keterampilan24 berpikir kreatif dan berpikir kritis25. Berpikir kreatif tersebut dapat mengembangkan individu menjadi lebih inovatif, memiliki kreativitas yang baik, ideal dan imajinatif serta berpeluang untuk berpikir26 secara reflektif27 sehingga dapat menyelesaikan masalah yang dihadapi dalam keadaan apapun28. HOTS merupakan bagian dari produk fikir taksonomi Bloom yang terdiri dari analizye (c4), Evalue (c5) dan create (c6) yang digunakan dalam penyususnan soal29 yang dijabarkan pada tabel di bawah ini:

Tabel 1: Indikator HOTS Berdasar Taksonomi Bloom

\begin{tabular}{ll}
\hline \multicolumn{1}{c}{ Kategori } & \multicolumn{1}{c}{ Deskripsi } \\
\hline Menganalisis (analyze) & Menspesifikasikan aspek elemen. \\
& Kata kerja: membandingkan, \\
& memeriksa, mengkritisi, menguji \\
\hline Mengevaluasi (evaluate) & Mengambil keputusan sendiri \\
& Kata kerjanya: evaluasi, menilai, \\
& menyanggah, memutuskan, \\
& memilih, mendukung. \\
\hline Mencipta (create) & Mengkreasikan ide sendiri \\
& Kata kerja: mengkonstruksi, desain, \\
& kreasi, mengembangkan, menulis \\
\hline
\end{tabular}

24 Lestari, Saepulrohman, and Hamdu, "Pengembangan Soal Tes Berbasis HOTS Pada Model Pembelajaran Latihan Penelitian Di Sekolah Dasar."

25 Achmad Fanani and Dian Kusmaharti, "Pengembangan Pembelajaran Berbasis HOTS (Higher Order Thinking Skill) Di Sekolah Dasar Kelas V," Jurnal Pendidikan Dasar 1 (n.d.): $1-11$.

26 Yee Mei Heong et al., "The Role of Higher Order Thinking Skills in Green Skill Development," in MATEC Web Of Conferences, 2016.

27 Razmawaty Mohamed and Othman Lebar, "Authentic Assessment in Assessing Higher Order Thinking Skills," International Journal of Academic Research in Business and Social Science 7, no. 2 (2017): 466-476.

28 Abdul Malik, Chandra Ertikanto, and Agus Suyatna, "Deskripsi Kebutuhan HOTS Assessment Pada Pebelajaran Fisika Dengan Metode Inkuiri Terbimbing," in Prosiding Seminar Nasional Fisika, 2015, http://journal.unj.ac.id/unj/index.php/prosidingsnf/article/view/5011.

29 Dodi Iskandar and Senam, "Studi Kemampuan Guru Kimia SMA Lulusan UNY Dala Mengembangkan Soal Uas Berbasis HOTS," Jurnal Inovasi Pendidikan Kimia 1, no. 1 (2015). 
Berdasarkan devinisi di atas, dapat diketahui bahwa HOTS merupakan sebuah kemampuan yang dimiliki peserta didik pada tingkatan level tinggi. Untuk mencapai tingkatan tersebut, tentunya harus dilalui melalui sebuah program yang tersusun secara kompleks dalam sebuah lebaga sekolah tersebut. Program yang dimaksud berupa RPP dan Silabus pada MI At-Taqwa GUPI Wojowalur Yogyakarta. Selanjutnya, ketercapaian dari program pembelajaran HOTS ini tentunya tidak terlepas dari dua koponen awal. Komponen tersebut diantaranya adalah perencanaa dan pelaksanaan. Telah diketahui bersama bahwa perencanaan merupakan proses yang dilakukan dalam menentukan tujuan yang ingin dicapai30. Selain itu, Anwar menjelaskan bahwa perencanaan merupakan kegiatan awal yang telah disusun sebelum dilakukan sebuah tindakan31. oleh karenanya, prencanaan memperoleh posisi penting dalam mencapai sebuah program yang telah disusun.

Selanjutnya, upaya yang tak kalah penting lainnya adalah pelaksanaan program yang telah terencana. Implementasi merupakan nama lain yang digunakan untuk menggantikan kata perencanaan32. Tanpa adanya pelaksanaan program, maka perencanaan sebagus apapun tak akan berguna dan tak memiliki imbas terhadap program tersebut. Hal ini dikarenakan kedua komponen antara perencanaan dan pelaksanaan merupakan satu kesatuan yang tak bisa dipisahkan. Penjelasan tersebut sesuai dengan penjelasan Terry dalam Zeris Dewindo yang menjelaskan bahwa pelaksanaan merupakan usaha menggerakkan setiap komponen guna mencapai sasaran yang hendak dicapai33. Begitupun pada program pembelajaran berbasis HOTS, dua tahap ini juga menjadi titik penentu tercapainya program tersebut. Ketercapaian level tertinggi ini dapat dilihat mulai dari perencanaan yang tertuang dalam silabus dan RPP serta pelaksanaanya yang terlihat pada proses pembelajaran di kelas.

Analisis progam pembelajaran tahun ajaran 2019/2020 bebasis HOTS dilakukan melalui penyajian data, dimana data tersebut dianalisis mengenai program perencanaan pembelajaran dan pelaksanaan progam pembelajaran. Data-data tersebut dikumpulkan berdasarkan hasil wawancara dan dokumentasi

30 Rusydi Ananda, Perencanaan Pembelajaran (Medan: LPPPI, 2019).

31 Anwar and Moch Idochi, Sistem Informasi Manajemen Dan Perencanaan Pebangunan Pendidikan (Bandung: Aksara, 1986).

32 Shaleh Assingkily and Nur Rohman, "Edupreneurship Dalam Pendidikan Dasar

Islam," JIP Jurnal Ilmiah PGMI) 2, no. 2 (2019), http://jurnal.radenfatah.ac.id/index.php/jip/article/view/3721.

33 Zeris Dewindo, "Pelaksanaan Pebelajaran Di TPQ Suarau Runcing Desan Timbulun Kenagariaan Surantih Kabupaten Pesisir Selatan," Jurnal Spektrum 2, no. 2 (2014), http://ejournal.unp.ac.id/index.php/pnfi/article/view/5053 . 
yang dilakukan oleh peneliti, sehingga diperoleh hasil penelitian yang terkait dengan analisis program pembelajaran tahun ajaan 2019/2020 sehingga data tersebut dapat menjawab rumusan masalah serta tujuan-tujuan penelitian yang ingin dicapai. Berikut adalah data yang peneliti peroleh selama penelitian:

\section{Program Perencanaan Pembelajaran Berbasis HOTS Di MI At-Taqwa GUPPI Wojowalur Daerah Istimewa Yogyakarta Tahun Ajaran 2018/2019}

Rumusan masalah pertama yang akan peneliti bahas disini mengenai perencanaan program pembelajaran berbasis HOTS. Dimana penelitian ini dilakukan di MI At-Taqwa GUPPI Wojowalur Daerah Istimewa Yogyakarta pada program pembelajaran tahun ajaran 2019/2020. Berbicara mengenai progam pembelajaran termasuk di dalamnya meliputi silabus dan juga rancangan perencanaan pembelajaran atau biasa disebut dengan RPP, pernyataan ini sejalan dengan lampiran pemerintah mengenai perarturan menteri pendidikan dan kebudayaan no 22 tahun 2016 tentang standar proses pendidikan dasar dan menengah.34.

Perencanaan program pembelajaran yang pertama akan dibahas adalah silabus, berikut perincian datanya:

\section{Silabus}

Silabus merupakan sebuah komponen utama dalam pengembangan RPP untuk mengarahkan kegiatan pembelajaran peserta didik dalam melakukan pembelajaran dan upaya yang dilakukan sekolah dalam upaya mencapai Kompetensi Dasar itu sendiri atau KD35. Untuk silabus di MI At-Taqwa sendiri sudah disediakan draftnya guru hanya menyesuaikan dengan kebutuhan dalam pembelajaran seperti yang dikatakan:

"Dari awal saya menjadi guru di sekolah MI At-Taqwa memang sudah ada mba draft silabusnya, saya hanya menyesuaikan saja dengan proses pembelajaran yang nanti akan berlangsung. Silabus yang dipake juga ada koordinasinya dalam"36.

Silabus yang digunakan di MI At-Taqwa Wojowalur oleh wali kelas VI sendiri terdapat tiga kolom, kolom pertama yaitu KD, kolom kedua materi pembelajaran dan kolom ketiga adalah kegiatan pembelajarannya. Dalam

34 Peraturan Menteri Pendidikan dan Kebudayaan Nomor 22 Tahun 2016 Tentang Standar Proses Pendidikan Dasar dan Menengah

35 Yayuk, Deviana, and Sulistyani, "Kemampuan Guru Dalam Implementasi Pembelajaran Dan Penilaian HOTS Pada Siswa Kelas 4 Sekolah Indonesia Bangkok Thailand."

36 Hasil Wawancara bersama wali kelas ibu ARD menggunakan via whatsapp (ketika masa PSBB sedang berlangsung) pada tanggal 28/04/2020 
penelitian ini hal yang ingin peneliti analisis adalah $\mathrm{KD}$ dan kegiatan pembelajaran yang terdapat dalam silabus, berikut pemaparannya silabus tahun pelajaran 2019/2020 di MI At-Taqwa GUPPI Wojowalur Tema 1 yang membahas mengenai Selematkan Makhluk Hidup, tema satu mengenai makhluk hidup, sub tema satu mengenai tumbuhan sahabatku dan pembelajaran pertama mata pelajaran IPA:

Tabel 4.1

Silabus Pembelajaran Mata Pelajaran IPA

\begin{tabular}{|c|c|c|}
\hline \multicolumn{3}{|c|}{ IPA } \\
\hline $\begin{array}{l}\text { Kompetensi Dasar } \\
\text { (KD) }\end{array}$ & $\begin{array}{c}\text { Materi } \\
\text { Pembelajaran }\end{array}$ & Kegiatan Pembelajaran \\
\hline $\begin{array}{l}\text { Membandingkan cara } \\
\text { perkembangbiakan } \\
\text { tumbuhan dan hewan } \\
\text { Menyajikan karya } \\
\text { tentang } \\
\text { perkembangbiakan } \\
\text { tumbuhan. }\end{array}$ & $\begin{array}{l}\text { Mengamati } \\
\text { tanaman dengan } \\
\text { perkembangbiak } \\
\text { an generative } \\
\text { dan manfaatnya }\end{array}$ & 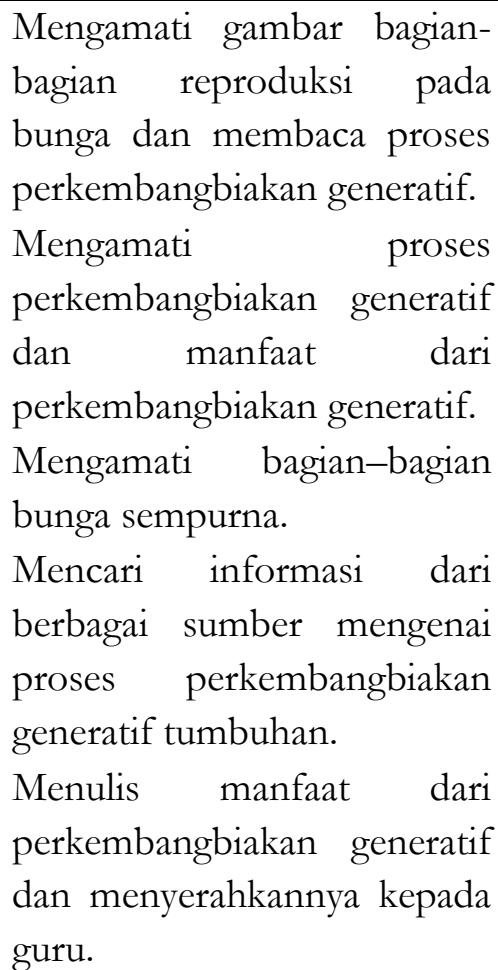 \\
\hline
\end{tabular}

KD 3.1 Membandingkan cara perkembangbiakan tumbuhan dan hewan, kata kerja pertama yaitu membandingkan yang termasuk kedalam dimensi kognitif C2.6 (Cognitif level 2 memahami kata kerja membandingkan). Dalam tujuan pendidkan, membandingkan melibatkan proses mendeteksi persamaan dan 
perbedaan antara dua atau lebih objek, peristiwa, ide, masalah atau situasi. Dalam materi perkembangbiakan tumbuhan dan hewan dengan KD 3.1 diharapakan peserta didik dapat melibatkan proses mendeteksi persamaan dan perbedaan antara pekembangbiakan tumbuhan dan hewan, dimana membandingkan juga dapat mendukung penalaran dengan analogi.

Turunan dari KD 3.1 dalam kolom kegiatan pembelajaran kalimat pertama, kedua, dan ketiga merupakan tahap awal yang dikembangkan dalam proses kegiatan pembelajaran dimana terdapat kata kerja "mengamati" yang termasuk kedalam dimensi kognitif tahap 1 yaitu mengingat atau sering disebut C1 (Cognitif level 1). Sejatinya mengamati merupakan melihat dan memperhatikan secara teliti37, dimana dalam silabus ini adalah mengamati gambar-gambar bunga, mengamati bagaimana proses perkembangbiakan tumbuhan, serta mengamati bagian-bagian bunga yang sebelumnya sudah dipelajari di kelas rendah. Mengamati inilah yang menjadikannya termasuk kedalam pengetahuan mengingat, yang cukup penting sebagai bekal untuk belajar yang bermakna dan menyelesaikan masalah. Dimana peserta didik mencari di memori jangka panjang suatu informasi yang baru saja diterima. Penerimaan informasi baru oleh peserta didik, memungkinkan peserta didik menentukan apakah informasi tersebut sesuai dengan pengetahuan yang telah dipelajari sebelumnya atau tidak, dimana peserta didik dapat mencari kesesuaian di antara keduanya.

Poin keempat sebagai turunan dari KD 3.1 juga dimana dalam kegiatan pembelajaran ini terdapat kata kerja "mencari" dalam kalimat "mencari informasi dari berbagai sumber mengenai proses perkembangbiakan generatif tumbuhan". Sejatinya dalam hal mencari berarti kita berusaha mendapatkan, menemukan, memperoleh38 materi-materi yang berkaitan dengan perkembangan generatif. Dimana dengan mencari kita dapat lebih memahami infomasi mengenai pembahasan tersebut yang dimana memahami termasuk kedalam dimensi kognitif tahap kedua yaitu tahap memahami atau sering disebut C2 (Cognitif level 2). Peserta didik dikatakan memahami ketika mereka dapat menghubungkan pengetahuan "baru" dan pengetahuan lama mereka. Lebih tepatnya, pengetahuan yang baru masuk dipadukan dengan skema-skema dengan kerangka kognitif yang ada39. Dimana peserta didik dapat mengklasifikasikasikan, menyimpulkan, mencontohkan, membandingkan materimateri yang berkaitan dengan pembahasan perkembangbiakan generatif dari

37 Kemendikbud, “KBBI V,” n.d.

38 Ibid.

39 Lorin W Anderson and David R Krathwohl, Kerangka Landasan Untuk Pembelajaran, Pengajaran, Dan Asesmen Revisi Taksonomi Pendidikan Bloom (Yogyakarta: Pustaka Pelajar, 2017). 
infomasi-informasi yang didapat dalam berbagai media informasi yang termasuk kategori memahami.

Selanjutnya KD 4.1 Menyajikan karya tentang perkembangbiakan tumbuhan, kata kerja pertama yaitu menyajikan. Dimana menyajikan atau mengemukakan 40 merupakan kata kerja yang bisa termasuk kedalam dimensi kognitif C3.2 (Cognitif level 3 mengaplikasikan kata kerja mengimplementasikan), dimana ketika menyajikan sebuah karya peserta didik dituntut untuk mengimplementasikan materi yang telah diterima menjadi sebuah karya. Tuntutan peserta didik dalam memilih alternatif-alternatif prosedur inilah maka dari itu peserta didik dituntut untuk memahami jenis masalahnya. Sehingga mengimplementasikan terjadi bersama kategori-kategori proses kognitif lain, seperti dimensi kognitif C2 yaitu memahami hingga kognitif C6 yaitu mencipta.

Poin kelima dalam kegiatan pembelajaran terdapat kata kerja "menulis" dalam kalimat "menulis manfaat dalam perkembangbiakan generatif". Menulis inilah yang menjadi sebuah kalimat turunan dari kata menyajikan sebuah karya yang terdapat dalam KD. Menuliskan informasi yang didapat termasuk kedalam dimensi kognitif tahap 4 yaitu tahap menganalisis atau sering disebut juga dengan kata C4 (Cognitif level 4). Dengan menuliskan sebuah informasi yang didapat oleh peserta didik diharapkan dapat memilih dan memilah potonganpotongan informasi yang relevan dan yang tidak relevan (membedakan) terhadap materi tersebut serta dapat menyusun dan menentukan potongan-potongan informasi tersebut (mengorganisasikan) dalam sebuah tulisan. Karena menganalisis merupakan perluasan dari Memahami atau pembuka awal dimensi kognitif rranah Mengevaluasi dan ranah Mencipta itu sendiri41.

Mencermati hasil pemaparan analisis silabus, terlihat bahwa dengan satu kata kerja yang terdapat dalam KD bisa menurunkan berbagai kata kerja dalam kegiatan pembelajaran yang beragam dan mendalam. Seperti halnya pada tema selamatkan makhluk hidup sub tema cintai bumiku pembelajaran pertama dimana KD pertama 3.1 yaitu membandingkan cara perkembangbiakan tumbuban dan bewan menghasilkan empat kata kerja dalam kegiatan pembelajaran dimana kata kerja pada kalimat pertama hingga kalimat ketiga mengandung unsur kognitif tahap C1 yaitu "mengamati" dan kalimat keempat menggunakan kata kerja "mencari" yang termasuk dimensi kognitif tahap memahami yaitu C2. Selanjutnya KD 4.1 yaitu Menyajikan karya tentang perkembangbiakan tumbuban

40 Kemendikbud, "KBBI V."

41 Anderson and Krathwohl, Kerangka Landasan Untuk Pembelajaran, Pengajaran, Dan Asesmen Revisi Taksonomi Pendidikan Bloom. 
menghasilkan satu turunan kata kerja menganalisis pada point kelima dimana pada point tersebut termasuk indikator HOTS.

Berbagai kata kerja dalam kegiatan pembelajaran inilah yang menjadi bekal awal para guru atau patokan para guru agar dapat menyusun RPP dengan lebih jelas. Dan dibawah ini peneliti akan membahas RPP sebagai turunan dari silabus yang sudah dipaparkan penjelasannya, berikut pemaparannya RPP nya

\section{Rencana Pelaksanaan Pembelajaran (RPP)}

Perencanaan selanjutnya yang dilakukan oleh guru adalah pembuatan rencana pelaksanaan pembelajaran atau biasa disebut dengan RPP. Di dalam RPP secara rinci harus memuat: Identitas satuan pendidikan serta indentitas mata pelajaran, Kompetensi Inti (KI), Kompetensi Dasar (KD), Indikator, Tujuan Pembelajaran, Kegiatan Pembelajaran, Sumber dan Materi Pembelajaran, Bentuk Instrumen Penilaian dan Pedoman Penilaian yang sesuai dengan kebijakan yang dikeluarkan pemerintah tentang pembuatan RPP. Berikut adalah contoh RPP kelas VI MI At-Taqwa dapat dlihat dalam lampiran 1 sekaligus RPP yang peneliti akan analisis, sebagai berikut:

RPP di MI ini sudah mengikuti RPP revisi 2019 namun sayangnya RPP ini tidak dibuat sendiri oleh wali kelas melainkan sudah disediakan oleh pihak sekolah dimana RPP tersebut digunakan untuk MI dalam satu kecamatan Wojowalur. Berikut hasil wawancara yang dilakukan oleh peneliti dengan narasumber bu ADR salah satu wali kelas di MI At-Taqwa yang menyatakan:

"RPP yang dirancang dalam pembelajaran tidak murni saya yang buat sendiri mba, karena ketika saya masuk ke sekolah tersebut sebagai guru baru, RPP nya sudah disediakan dari pihak sekolah dan dalam penggunaan RPP tersebut semua sama dalam satu kecamatan mba. Namun tetap saya sebagai wali kelas VI dalam prosesnya menambahkan metode-metode yang menarik dan menggunakan media-media pembelajaran atau alat peraga yang dapat mendukung pembelajaran di dalam kelas. Diantara metode yang saya gunakan adalah metode tanya jawab, metode diskusi dan saya juga pernah sesekali memberikan pretest dan postest dalam proses pembelajaran dikelas" 42 .

Sejatinya RPP dibuat oleh guru mata pelajaran yang bersangkutan, karena hanya guru yang bersangkutan yang paham terhadap bagaimana situasi dan kondisi dalam proses pembelajaran. Dalam peencanaan program pembelajran berbasis HOTS ini yang akan kita bahas adalah RPP tema 1 mengenai

42 Hasil Wawancara bersama wali kelas ibu ARD menggunakan via whatsapp (ketika masa PSBB sedang berlangsung) pada tanggal 28/04/2020 
selamatkan makhluk hidup sub tema 1 mengenai tumbuhan sahabatku dan pembelajaran pertama yang akan eneliti bahas disini adalah mata pelajaran IPA mengenai perkembangbiakan secara generatif.

Wali kelas ARD dalam proses pembelajarannya secara tidak langsung sudah menerapkan metode yang dapat meningkatkan HOTS yaitu metode tanya jawab dan diskusi. Dimana guru yang menggunakan metode tanya jawab ini akan menghadirkan kehangatan, antusiasme peserta didik, dan bergembira dalam proses pembelajaran43. Selain itu penanaman berpikir kritis sudah diterapkan sesuai dengan silabus yang ada yaitu pada kata kerja menulis. Menuliskan informasi yang didapat termasuk kedalam dimensi kognitif tahap 4 yaitu tahap menganalisis atau sering disebut juga dengan kata C4 (Cognitif level 4). Dengan menuliskan sebuah informasi yang didapat oleh peserta didik diharapkan dapat memilih dan memilah potongan-potongan informasi yang relevan dan yang tidak relevan (membedakan) terhadap materi tersebut serta dapat menyusun dan menentukan potongan-potongan informasi tersebut (mengorganisasikan) dalam sebuah tulisan. Karena menganalisis merupakan perluasan dari Memahami atau pembuka awal Mengevaluasi dan Mencipta itu sendiri44.

\section{Tabel 4.2}

Potongan Kegiatan Inti dalam RPP

Siswa kemudian menulis manfaat dari perkembangbiakan generatif dan menyerahkannya kepada guru. Critical Thinking and Problem Solving

Dimana kata kerja menulis manfaat dari materi diatas merupakan salah satu penerapan HOTS yang ada dalam kegiatan inti RPP dengan dimensi anah kognitif termasuk kedalam menganalisis C4 tema mengenai selamatkan makhluk hidup sub tema tumbuhan sahabatku pembelajaran pertama

\section{Pelaksanaan Program Pembelajaran Berbasis HOTS Di MI At-Taqwa GUPPI Wojowalur Yogyakarta Tahun Ajaran 2018/2019}

Kegiatan pembelajaran sehari-hari di MI At-Taqwa GUPPI Wojowalur Yogyakarta. MI At-Taqwa ini merupakan MI yang diunggulkan dilingkungan sekitar MI, karena MI ini mengunggulkan tentang program keagamaannya. Seperti hasil wawancara kami dengan narasumber sebagai berikut:

43 Yani, Cara Mudab Menulis Soal HOTS Higher Order Tbinking Skilss Suatu Pendekatan "Jarak Nalar" Yang Dilengkapi Dengan Pembelajaran Berorientasi Keterampilan Berpikir Tingkat Tinggi.

44 Anderson and Krathwohl, Kerangka Landasan Untuk Pembelajaran, Pengajaran, Dan Asesmen Revisi Taksonomi Pendidikan Bloom. 
"Dilingkungan sekitar MI tepatnya di desa Wojowalur, MI diunggulkan mba oleh warga sekitar karena pada jam pertama itu setiap hari dilakukan tahfidz di masing-masing kelas bersama pendidik sebagai pembimbing, dan jika sudah jam istirahat maka peserta didik akan melakukan sholat dhuha, lalu siangnya dilanjutkan dengan tahsin. Namun selain penggunggulan dalam bidang agama kami juga di sekolah berusaha meningkatkan dalam hal proses pembelajarannya mba seperti pemberian media pembelajaran, penambahan jam kelas jika ada peseta didik yang kurang paham dan meningkatkan kreatifitas para peseta didik dengan beberapa kegiatan ekstrrakulikuler. Salah satu kegiatan ekstrakuliernya seperti pramuka dan membatik." 45

Pernyataan ini diperkuat oleh bukti kartu hafalan santri juz 30 MI At-Taqwa Wojowalur Yogyakarta yang peneliti temukan didalam kelas ketika peneliti melakukan observasi:

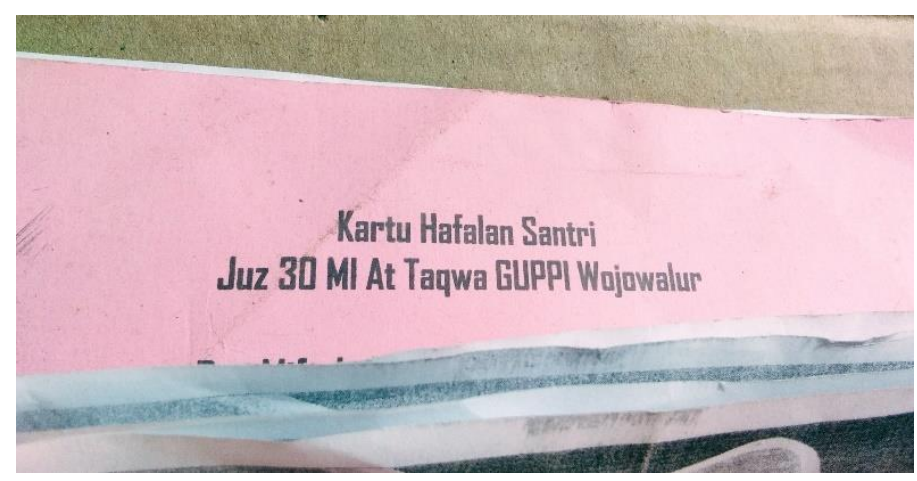

\section{Gambar 4.1 Kartu hafalan santri juz 30 MI At-Taqwa Wojowalur}

Selain hafalan juz 30 yang dilaksanakan sebelum dimulainya proses belajar mengajar, ada juga kegiatan ekstrakulikuler yang merupakan salah satu program yang ada di MI At-Taqwa yaitu kegiatan yang termasuk dalam pengembangan diri. Kegiatan jenis ini merupakan kegiatan di luar jam proses pembelajaran dikelas. Kegiatan ekstrakuliluker di MI At-Taqwa ini ada tiga yaitu membatik, pramuka dan TPA.

Membatik dilaksanakan pada hari rabu sekitar 2 jam an, membatik dihadirkan dalam kegiatan ekstrakulikuler ini sebagai sarana pemupukan dini agar cinta terhadap warisan nenek moyang kita selain mengasah minat bakat para peserta didik. Jenis batik yang dipelajari adalah jenis batik jumputan, batik

45 Hasil Wawancara bersama wali kelas ibu ARD menggunakan via whatsapp (ketika masa PSBB sedang berlangsung) pada tanggal 3/05/2020 
jumputan adalah jenis batik yang dikerjakan dengan teknik ikat celup yang menghasilkan gradasi warna yang cukup menaik. Dalam proses pencelupan ini sangat perlu ketelatenan dan kesabaran selain itu peserta didik bisa memahami jenis-jenis batik yang ada di Indonesia.

Ekstrakulikuler yang kedua yaitu pramuka atau praja muda karana yang berarti jiwa muda suka berkarya. Dengan harapan penerapan pramuka sejak usia dasar dapat meningkatkan kreativitas para peserta didik sesuai makna dari pamuka itu sendiri. Ekstakulikuler pramuka sendiri di MI At-Taqwa GUPPI Wojowalur dilaksanakan pada hari sabtu setelah pulang sekolah

Ekstrakulikuler TPA dilaksanakan dua kali dalam seminggu berbeda dengan ekstrakulikuler yang lain hanya satu kali dalam seminggu yaitu setiap hari selasa dan kamis yang langsung dilakukan oleh guru khusus TPA. TPA atau Taman Pendidikan Al-Qur'an diadakan bertujuan untuk memberikan pengajaran alQur'an sejak dini serta lebih memahami dasar-dasar al-Qur'an yang dimana penekanan terhadap pemberian dasar-dasar membaca al-Qur'an.

Selain ketiga kegiatan ekstrakulikuler pelaksanaan program pembelajaran di MI At-Taqwa Wojowalur Yogyakarta juga ada kegiatan tatap muka. Kegiatan tatap muka ini dilakukan pada hari senin sampai sabtu masuk kedalam kelas pukul 07.00 WIB dan pada jam pertama dilakukan tahfidz selanjutnya istirahat pertama dari pukul 09.20-09.40 dan istirahat kedua dilakukan pada pukul 11.3012.00 lalu pembubaran kelas atau jam pulang sekolah pukul 13.00 WIB kecuali hari jumat pukul 11.00 .

Pelaksanaan program pembelajaran tatap muka ini adalah pengaplikasian dari RPP. MI At-Taqwa GUPPI Wojowalur Yogyakarta melaksanakan program pembelajaran tematik, dimana menurut Sudarwan dalam Usmaedi mengatakan bahwa tematik terpadu sangat relevan dengan HOTS yang termasuk kedalam kurikulum 201346. HOTS juga temasuk kedalam salah satu aspek kognitif dan tema besar yang akan kita bahas dalam penelitian ini dimana HOTS sendiri termasuk kedalam taksonomi yang dikelompokkan menjadi tiga ranah besar yang diantaranya adalah ranah kognitif, afektif, psikomotorik yang sudah diterapkan di Indonesia dan tertuang dalam undang-undang nomor 20 tahun 2003 tentang sistem pendidikan nasional dalam bentuk rumusan sikap, pengetahuan, dan keterampilan47. Namun dalam penelitian ini lebih memfokuskan kepada kelompok anah kognitif.

46 Usmaedi, "Menggagas Pembelajaran HOTS Pada Anak Usia Sekolah Dasar."

47 Lampiran peratutan menteri pendidikan dan kebudayaan nomor 22 tahun 2016 tentang standa proses pendidikan dasar dan menengah 
Pelaksanaan pembelajaran merupakan salah satu program yang ada di MI At-Taqwa yaitu kegiatan tatap muka yang merupakan proses interaksi antara peserta didik dengan pendidik. Untuk mampu menyelenggarakan pembelajaran berbasis HOTS, guru hendaknya memahami komponen-komponen yang ada dalam setiap diri para peserta didik dan mengintegrasikan satu sama lain sehingga berfungsi optimal baik segi indra, otak, persepsi, atensi, motivasi, emosi, yang merupakan komponen internal yang ada dalam setiap diri peserta didik48.

Pada tahap penerapan RPP pembelajaran pertama, tema satu mengenai selamatkan makhluk hidup dan sub tema satu mengenai tumbuhan sahabatku, wali kelas melakukan kegiatan inti yang membahas mengenai proses perkembangbiakan generatif tumbuhan. Peserta didik dituntut mengamati bagian-bagian bunga yang ada digambar, dan mengeluarkan bunga sepatu atau bibiscus rosa sinensin yang sudah ditugaskan pada pertemuan sebelumnya.

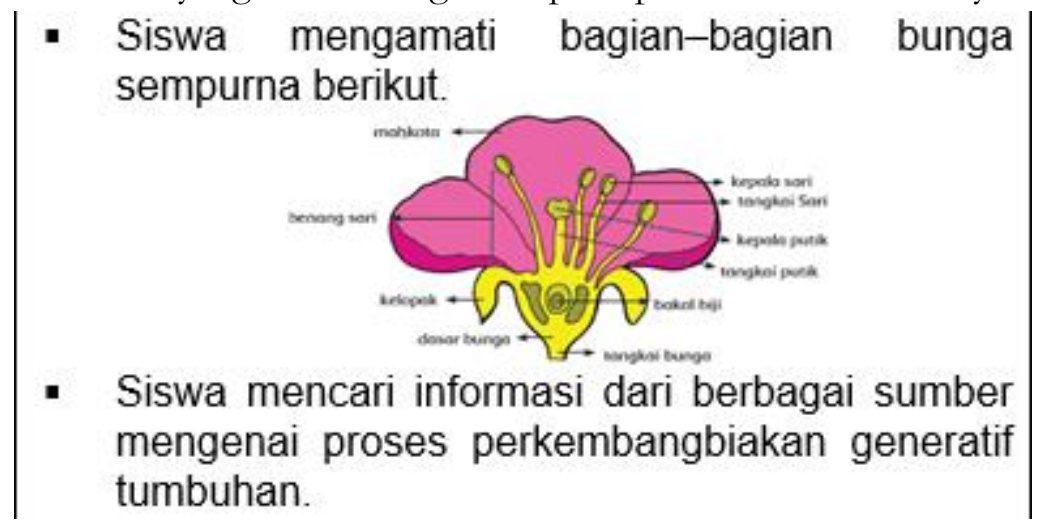

\section{Gambar 4.2 Perkembangan generatif tumbuhan pada bunga sepatu}

Setelah peserta didik mengamati bagian-bagian bunga peserta didik kemudian berdiskusi dengan kelompoknya, dimana diskusi ini merupakan salah satu metode yang dapat untuk memecahkan suatu permasalahan dan juga peningkatan berpikir kreatif yang menjadi salah satu indikator HOTS49. Dimana konsep pemecahan masalah atau project based learning selain menjadi salah satu

48 Helmawati, Pembelajaran Dan Penilaian Berbasis HOTS (Higher Order Thinking Skills) (Bandung: PT Remaja Rosdakarya, 2019).

49 La Moma, "Pengembangan Kemampuan Berpikir Kreatif Dan Pemecahan Masalah Matematis Mahasiswa Melalui Metode Diskusi," Cakrawala Pendidikan 36, no. 2 (2017): 130-139, https://journal.uny.ac.id/index.php/cp/article/view/10402. 
pengertian indikator juga termasuk pada peraturan pemerintahan nomo 22 tahun 201650

- Siswa mencari bunga di lingkungan sekolah dan mengamati bagian-bagiannya. Siswa kemudian menggambar bagian-bagian bunga tersebut.

\section{Gambar 4.3 Proses pembelajaran dalam kegaitan inti}

Selain peserta didik ditugaskan membawa bunga sepatu yang memiliki bagian-bagian bunga sempurna. Peserta didik pun dalam proses pembelajaran melakukan aktifitas di luar kelas. Sehingga pemahaman yang di dapat adalah pengalaman yang menimbulkan kesan bermakna bagi pesera didik ini sejalan dengan apa yang dipaparkan oleh Budi Taqwan51, Ach Amirudin52, bahwa pembelajaran diluar kelas dapat berpengaruh tehadap kemampuan pemecahan masalah dan juga meningkatkan kreatifitas anak. Dimana pembelajaran bermakna merupakan salah satu rancangan dalam pembelajaran HOTS itu sendiri53.

Mencermati hasil pemaparan yang guru ARD paparkan, adanya pembelajaran yang dilakukan di dalam dan di luar kelas membuat pembelajaran lebih bevariasi serta dengan penggunaan beberapa metode yang bervariasi dalam proses pembelajaran yang dapat meningkatkan HOTS.

\section{- Siswa membandingkan hasil gambarnya dengan gambar teman yang lain. \\ - untuk mencari persamaan dan perbedaannya. Jika terdapat perbedaan, siswa diminta menjelaskan perbedaan tersebut.}

\section{Gambar 4.4 Proses pembelajaran dalam kegaitan inti}

50 Lampiran peratutan menteri pendidikan dan kebudayaan nomor 22 tahun 2016 tentang standa proses pendidikan dasar dan menengah

51 Budi Taqwan and Saleh Haji, "Pengaruh Pembelajaran Luar Kelas (Outdoor Learning) Terhadap Kemampuan Pemecahan Masalah Siswa Kelas VII SMP Negeri 05 Seluma," Jurnal Pendidikan Matematika Raflesia 4, no. 1 (2009): 10-18, http:// ejournal.unib.ac.id/index.php/jpmr.

52 Ach Amiudin and Utami Widiati, "Pentingnya Pengembangan Bahan Ajar Tematik Untuk Mencapai Pembelajaran Bermakna Bagi Siswa Sekolah Dasar," in Prosiding Seminar Nasional Mahasiswa Kerjasama Direktorat Jenderal Guru Dan Tenaga Kependidikan Kemendikbud 2016, 2017, http://pasca.um.ac.id/wp-content/uploads/2016/09/Prosiding-Semnas-Dikdas2016.pdf.

53 Rahayu Pristiwati, “Tantangan Rancangan Pembelajaran Dalam Era Kompetensi Abad 21 Untuk Meningkatkan Kemampuan Keprofesionalan Dan Mengelola Pembelajaran Bermakna," Jurnal Abdimas 23, no. 2 (2019): 125-127, https://journal.unnes.ac.id/nju/index.php/abdimas/article/view/17882. 
Dalam hal menjelaskan siswa juga dituntut untuk memiliki sifat percaya diri dalam mengutarakan pendapat. Dan menerima pendapat teman-teman peserta didik yang lain.

\section{- Siswa kemudian menulis manfaat dari perkembangbiakan generatif dan menyerahkannya kepada guru. Critical Thinking and Problem Solving}

Gambar 4.5 Proses pembelajaran dalam kegaitan inti

Penulisan manfaat terhadap perkembangbiakan geneatif dapat menumbuhkan kemampuan berpikir kreatif dan pemecahan masalah merupakan bagian dari pengertian HOTS itu sendiri dimana siswa dituntut dalam menyelesaikan masalah tentang apa saja yang menjadi manfaat perkembangbiakan tumbuhan secara generatif. Dengan demikian mau tidak mau peserta didik dituntut menyelesaikan masalah dengan cara mencari tau dari berbagai sumber yang ada, dan diwaktu yang sama peserta didik dapat membedakan mana yang relevan dan yang tidak relevan serta siswa pun dituntun berpikir secara kreatif dalam mengorganisasikan secara struktur potonganpotongan informasi kedalam sebuah tulisan yang nantinya dikumpulkan kepada wali kelas. Tahap ini termasuk tahap menganalisis dalam tingkatan tahap dimensi kognitif Anderson dimana tingkatan analisis merupakan perluasan dalam pemahaman terhadap suatu materi54.

\section{SIMPULAN}

Adapun hasil penelitian tentang analisis program pembelajaran berbasis Higher Order Thinking Skills (HOTS) di MI At-Taqwa GUPPI Wojowalur Daerah Istimewa Yogyakarta Tahun Ajaran 2018/2019 yang dibentangkan di atas dapat ditarik kesimpulan bahwa (1) Program pembelajaran HOTS tahun ajaran 2018/2019 guru melaksanakan perencanaan pembelajaran dengan menggunakan silabus dan RPP yang berbasis HOTS (2) Program pelaksanaan pembelajaran HOTS tahun ajaran 2018/2019 guru sudah menggunakan variasi dalam penentuan metode yang berbasis HOTS seperti diskusi, tanya jawab dan kemampuan berargumentasi peserta didik.

54, Lorin W. Anderson \& David R. Krathwohl, 2017, Kerangka Landasan Untuk Pembelajaran, Pengajaran, Dan Asesmen Revisi Taksonomi Pendidikan Bloom, Yogyakarta: Pustaka Pelajar 


\section{REFERENSI}

Amiudin, Ach, and Utami Widiati. "Pentingnya Pengembangan Bahan Ajar Tematik Untuk Mencapai Pembelajaran Bermakna Bagi Siswa Sekolah Dasar." In Prosiding Seminar Nasional Mahasiswa Kerjasama Direktorat Jenderal Guru Dan Tenaga Kependidikan Kemendikbud 2016, 2017. http://pasca.um.ac.id/wp-content/uploads/2016/09/Prosiding-SemnasDikdas-2016.pdf.

Ananda, Rusydi. Perencanaan Pembelajaran. Medan: LPPPI, 2019.

Anderson, Lorin W, and David R Krathwohl. Kerangka Landasan Untuk Pembelajaran, Pengajaran, Dan Asesmen Revisi Taksonomi Pendidikan Bloom. Yogyakarta: Pustaka Pelajar, 2017.

Anni Prastiwi, Sriyono, Nurhidayati. "Pengembangan Modul Fisika Berbasis Masalah Untuk Meningkatkan High Order Thinking Skills (Hots) Siswa Sma." RADIASI: Jumal Berkala Pendidikan Fisika 9, no. 1 (2016): 1-6.

Anwar, and Moch Idochi. Sistem Informasi Manajemen Dan Perencanaan Pebangunan Pendidikan. Bandung: Aksara, 1986.

Ariyana, Yoki, Ari Pudjiastuti, Reisky Bestary, and Zamroni. Buku Pegangan Pembelajaan Berorientasi Pada Keterampilan Berpikir Tingkat Tinggi "Program Peningkatan Kompetensi Pembelajaran Berbasis Zonasi." Jakarta: Direktorat Jenderal Guru dan Tenaga Kependidikan Kementrian Pendidikan dan Kebudayaan, 2018.

Assingkily, Shaleh, and Nur Rohman. "Edupreneurship Dalam Pendidikan Dasar Islam." JIP (Jurnal Ilmiah PGMI) 2, no. 2 (2019). http://jurnal.radenfatah.ac.id/index.php/jip/article/view/3721.

Dewindo, Zeris. "Pelaksanaan Pebelajaran Di TPQ Suarau Runcing Desan Timbulun Kenagariaan Surantih Kabupaten Pesisir Selatan." Jurnal Spektrum 2, no. 2014 . http://ejournal.unp.ac.id/index.php/pnfi/article/view/5053 .

Fanani, Achmad, and Dian Kusmaharti. "Pengembangan Pembelajaran Berbasis HOTS (Higher Order Thinking Skill) Di Sekolah Dasar Kelas V.” Jurnal Pendidikan Dasar 1 (n.d.): 1-11.

Fitrianawati, Meita, and Aan Hendroanto. "Pelatihan Pembelajaran Berbasis HOTS Dan Pendidikan Matematika Realistik Bagi Guru SD Di Kabupaten Sleman," no. September (2019): 1-7.

Helmawati. Pembelajaran Dan Penilaian Berbasis HOTS (Higher Order Thinking Skills). Bandung: PT Remaja Rosdakarya, 2019.

Heong, Yee Mei, Lai Chee Sern, Tee Tze Kiong, and Mimi Mohaffyza. "The Role of Higher Order Thinking Skills in Green Skill Development." In MATEC Web OfConferences, 2016.

Herawati, Rahayu, W S Rustono, and Ghullam Hamdu. "Pengembangan Asesmen Hots Pada Pembelajaran Berbasis Masalah Tema Bermain Dengan Benda-Benda Di Sekitar." PEDADIDAKTIKA: Jurnal Ilmiah Pendidikan Guru Sekolah Dasar 1, no. 2 (2017): 151-159. 
Indriani, Fitri. "Kompetensi Pedagogik Mahasiswa Dalam Mengelola Pembelajaran Tematik Integratif Kurikulum 2013 Pada Pengajaran Micro Di PGSD UAD Yogyakarta." Jurnal Profesi Pendidikan Dasar 2, no. 2 (2015): 87-94. https://journal.upy.ac.id/index.php/es/article/view/362.

Iskandar, Dodi, and Senam. "Studi Kemampuan Guru Kimia SMA Lulusan UNY Dala Mengembangkan Soal Uas Berbasis HOTS." Jurnal Inovasi Pendidikan Kimia 1, no. 1 (2015).

Iskandar, Wahyu, Nur Rohman, and Muhammad Yusuf. "Kontribusi Pemikiran Imre Lakatos (1922-1974) Dalam Pendekatan Berbasis Saintifik Di Madrasah Ibtidaiyah." In Proceeding International Conference On Islamic Education (ICIED), 13-21, 2019. http://conferences.uinmalang.ac.id/index.php/icied/article/view/1060.

Kastarina, Yuni, Tegus S Karniman, and Anggraini. "Penerapan Model Pembelajaan Kooperatif Tipe Team Assisted Individualization Untuk Meningkatkan Hasil Belajar Siswa Pada Fungsi Komposisi Di Kelas XI IPA I SMAN 7 Palu." AKSIOMA Jurnal Pendidikan Matematika 5, no. 3 (2016): 269-281.

Kemendikbud. "KBBI V," n.d.

Kuntarto, Eko, Alirmansyah Alirmansyah, and Agung Rimba Kurniawan. "Kemampuan Mahasiswa PGSD Dalam Merancang Dan Melaksanakan Pembelajaran Berbasis High Order Of Thinking Skills." Jurnal Kiprah 7, no. 2 (2019): 107-116.

Lestari, Anggi, Asep Saepulrohman, and Ghullam Hamdu. "Pengembangan Soal Tes Berbasis HOTS Pada Model Pembelajaran Latihan Penelitian Di Sekolah Dasar" (2016): 74-83.

Lestari, Karunia Eka, and Mokhamad Ridwan Yudhanegara. Penelitian Pendidikan Matematika. Bandung: Refika Aditama, 2017.

Malik, Abdul, Chandra Ertikanto, and Agus Suyatna. "Deskripsi Kebutuhan HOTS Assessment Pada Pebelajaran Fisika Dengan Metode Inkuiri Terbimbing." In Prosiding Seminar Nasional Fisika, 2015. http://journal.unj.ac.id/unj/index.php/prosidingsnf/article/view/5011.

Mohamed, Razmawaty, and Othman Lebar. "Authentic Assessment in Assessing Higher Order Thinking Skills." International Journal of Academic Research in Business and Social Science 7, no. 2 (2017): 466-476.

Moma, La. "Pengembangan Kemampuan Berpikir Kreatif Dan Pemecahan Masalah Matematis Mahasiswa Melalui Metode Diskusi." Cakrawala Pendidikan 36, no. 2 (2017): 130-139. https://journal.uny.ac.id/index.php/cp/article/view/10402.

Muchtar, Hartati. "Penerapan Penilaian Autentik Dalam Upaya Peningkatan Mutu Pendidikan." Jurnal Pendidikan Penabur 14, no. 9 (2010): 68-76. https://www.academia.edu/download/51966178/jurnal-No14-Thn9Juni2010.pdf\#page $=76$.

Mursid, R, Abdul Hasan Saragih, and Naeklan Simbolon. "Pengaruh Media 
Pembelajaran Berbasis TIK Dan Sikap Inovasi Terhadap Hasil Belajar Perencanaan Pembelajaran Dengan HOTS." Jurnal Teknologi Informasi \& Komunikasi Dalam Pendidikan 4, no. 2 (2017): 179-187.

Murtikusuma, Randi Pratama, Arif Fatahillah, and Lioni Anka Monalisa. "Pengembangan Rancangan Pembelajaran Matakuliah Kombinatorika Berbasis Kerangka Kualifikasi Nasional Indonesia (KKNI) Dan Local Wisdom (Development of Combinatorics Learning Plan Based on NationalQualification Framework and Local Wisdom)." Jurnal edukasi 4, no. 3 (2014): $41-44$. https://jurnal.unej.ac.id/index.php/JEUJ/article/view/6300 .

Pristiwati, Rahayu. "Tantangan Rancangan Pembelajaran Dalam Era Kompetensi Abad 21 Untuk Meningkatkan Kemampuan Keprofesionalan Dan Mengelola Pembelajaran Bermakna." Jurnal Abdimas 23, no. 2 (2019): 125-127. https://journal.unnes.ac.id/nju/index.php/abdimas/article/view/17882.

Setiawati, Wiwik, Oktavia Asmira, Yoki Ariyana, Reisky Bestary, and Ari Pudjiastuti. "Program Pengembangan Keprofesian Berkelanjutan (PKB) Melalui Peningkatan Kompetensi Pembelajaran (PKP) Berbasis Zonasi." In Buku Penilaian Beroientasi Higher Order Thinking Skills. Jakarta: Direktorat Jendral Guru dan Tenaga Kependidikan Kementerian Pendidikan dan Kebudayaan, 2019.

Suprapto, Anas. "Posisi Dan Peran Guru Dalam Pola Kurikulum 2013." J-PAI: Jurnal Pendidikan Agama Islam 3, no. 1 (2016): 89-94. https://doi.org/10.18860/jpai.v3i1.3993 .

Tanujaya, Benidiktus, Jeinne Mumu, and Gaguk Margono. "The Relationship between Higher Order Thinking Skills and Academic Performance of Student in Mathematics Instruction." International Education Studies 10, no. 11 (2017): 78-85.

Taqwan, Budi, and Saleh Haji. "Pengaruh Pembelajaran Luar Kelas (Outdoor Learning) Terhadap Kemampuan Pemecahan Masalah Siswa Kelas VII SMP Negeri 05 Seluma." Jurnal Pendidikan Matematika Raflesia 4, no. 1 (2009): 10-18. http://ejournal.unib.ac.id/index.php/jpmr.

Troffer. Future Shock: A Book. That Will Resphape Our Thinking. London: Prantice Hall, 1976.

Uce, Loeziana. "Realitas Aktual Praksis Kurikulum: Analisis Terhadap KBK, KTSP Dan Kurikulum 2013." Jurnal Ilmiah Didaktika 16, no. 2 (2016): 216229. http://dx.doi.org/10.22373/jid.v16i2.596.

Usmaedi. "Menggagas Pembelajaran HOTS Pada Anak Usia Sekolah Dasar." JPSD 3, no. 1 (2017).

Wibawa, Ramadhan Prasetya, and Dinna Ririn Agustina. "Peran Pendidikan Berbasis Higher Order Thinking Skills (Hots) Pada Tingkat Sekolah Menengah Pertama Di Era Society 5.0 Sebagai Penentu Kemajuan Bangsa Indonesia." EQUILIBRIUM Jurnal Imiah Ekonomi dan Pembelajarannya 7, 
no. 2 (2019): 137-141.

Yani, Ahmad. Cara Mudah Menulis Soal HOTS Higher Order Thinking Skilss Suatu Pendekatan "Jarak Nalar" Yang Dilengkapi Dengan Pembelajaran Berorientasi Keterampilan Berpikir Tingkat Tinggi. Bandung: PT Refika Aditama, 2019.

Yayuk, Erna, Tyas Deviana, and Nawang Sulistyani. "Kemampuan Guru Dalam Implementasi Pembelajaran Dan Penilaian HOTS Pada Siswa Kelas 4 Sekolah Indonesia Bangkok Thailand." JINOP (Jurnal Inovasi Pembelajaran) 5, no. 2 (2019): 107-122. 